\title{
Simplified Gender Rule
}

Both to streamline the presentation and to serve as a learning tool, the text will employ the following "Simplified Gender Rule" that "predicts" the correct gender for more than 96 percent of all Spanish nouns.

1. Nouns having one of the following endings are assumed to be feminine:
a) $-a$
b) -ión
c) $-d$
d) -umbre
e) $-i e$
f) $-e z$
g) - triz
h) -sis /-tis (Greek words)

2. Nouns ending in -ista are assumed to be both masculine and feminine.

3. All other nouns are assumed to be masculine.

ONLY NOUNS WHOSE GENDER IS "UNPREDICTABLE" WILL BE EXPLICITLY MARKED.

Thus:

$\begin{array}{ll}\text { rosa } & \text { rose } \\ \text { tema }(\mathrm{m} .) & \text { theme } \\ \text { libro } & \text { book } \\ \text { mano (f.) } & \text { hand } \\ \text { nación } & \text { nation } \\ \text { avión (m.) } & \text { airplane } \\ \text { corazón } & \text { heart } \\ \text { razón (f.) } & \text { reason } \\ \text { periodista } & \text { journalist } \\ \text { evangelista }(\mathrm{m} .) & \text { Evangelist (author of one of the four NT gospels) }\end{array}$

Annex A examines in more detail the accuracy of this "rule" and lists some of the principal exceptions. 
In general, Spanish is quite flexible in forming feminine nouns from masculine ones by:

(a) changing the final - $o$ to $-a$

(b) adding - $a$ to a noun or adjective ending in -or, -án, -ín, -ón

(c) adding - $a$ to a national or regional identifier ending in a consonant For (b) and (c), the final-syllable written accent, if any, disappears in the feminine.

Masculine Feminine English

(a) gato gata cat

(b) director directora director

$\begin{array}{lll}\text { holgazán } & \text { holgazana } & \text { lazy, loafer } \\ \text { bailarín } & \text { bailarina } & \text { dancing, dancer } \\ \text { ladrón } & \text { ladrona } & \text { thieving, thief } \\ \text { español } & \text { española } & \text { Spanish, Spaniard } \\ \text { francés } & \text { francesa } & \text { French, Frenchman /Frenchwoman }\end{array}$

To simplify the presentation, masculine forms only will generally be shown for nouns and adjectives that follow these patterns, except in cases where there is a change in written accent, or where English has a distinct female form. Examples:

$\begin{array}{ll}\text { ladrón (-ona) } & \text { thieving, thief or larcenist } \\ \text { ciervo, cierva } & \text { deer, stag, doe }\end{array}$

For "people" nouns not having one of the above endings, the masculine and feminine forms are generally identical. This will frequently be highlighted by using the abbreviation $m$./f. Thus:

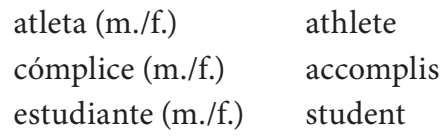

Finally, there are a very small number of "object" nouns that can be either masculine or feminine, with no change in meaning. These will also be marked with $m . / f$. For example:

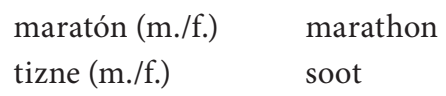


THIS PAGE INTENTIONALLY LEFT BLANK 
Spanish Vocabulary 
THIS PAGE INTENTIONALLY LEFT BLANK 